\title{
CONTRIBUTIONS
}

CERIF: S142

\author{
Hon. Frank J. LaBuda*
}

\section{STALKING IN NEW YORK}

\section{INTRODUCTION}

In a society people enact laws to protect the innocent. These laws often reflect the morals, values and concerns of that society. In ever changing societies laws too must change to protect the innocent. The United States is a very rapid changing society, and with changes in society come new concerns regarding social deviancy. In recent times, the issue of "stalking" has grown to become a concern for public and individual safety. In response to that concern, both the Judicial and Legislative Branches of Government have responded by enacting new laws and interpretations to protect people from Stalkers. This article will explain New York State's response to the social deviancy of Stalking.

Stalking, in common parlance today, is defined as "closely following and watching another person for a long period of time in a way that is threatening and dangerous" (Merriam-Webster's Dictionary).

As a general matter, even where attempts to criminalize stalking and to punish stalkers have been made, these efforts have often neglected the concerns of the victims of stalkers who are overwhelmingly women. This is not surprising, in view of the gendered nature of this crime, and given that "the politics of battered and raped women [has] become estranged from local [victim support] schemes, the State, and much of the criminal justice system." ${ }^{1}$

* Frank J. LaBuda has been an elected New York State Judge since 1996 and presides over criminal and civil cases at NY States highest trial court, Supreme Court. He is also a lecturer on U.S. Constitutional Law and Trial Procedures at many Universities in Eastern Europe and West Africa.

1 Balboni Anti Stalking Legislation Gains Statewide Support, News from State Senator Michael A.L. Balboni (Office of N.Y. State Sen. Michael A.L. Balboni, Albany, N.Y.), May 4, 1999. 
When first proposed in 1992, the New York anti-stalking legislation was only ten to fifteen lines long; the law ultimately enacted was over ten single-spaced pages long. By being the last of the fifty states in the U.S. to enact anti-stalking legislation, New York had the advantage of learning from the examples, both positive and negative, of other states. One such example is that of providing protection for family members in extended households; Awhere the woman is being stalked and all of a sudden the Stalker switches and goes after the sister or the mother, and $\mathrm{it}=\mathrm{s}$ all wrapped into the same kind of offense. Indeed, the New York legislation not only protects against this, but takes the concept of family one appropriate step further, in that, for purposes of the Act, "members of the same family or household, are included." (See, Balboni, N1)

The nature of stalking has been described as Aan individualized campaign of terrorism against the victim, and has factors which the law enforcement communities are very familiar with. It should be noted that the New York Legislature in criminalizing stalking set up a standard of intent that does not require that the stalker have a specific intent to stalk, but rather that the stalker intentionally engages in a course of conduct, which s/he "knew or reasonably should have known that such conduct" is likely to cause reasonable fear of material harm to the physical health, safety or property of the victim or a member of the victim's family, or the conduct causes material harm to the mental or emotional health of the victim or a member of the victim's family, or that the conduct "is likely to cause such person to reasonably fear that his or her employment is threatened, where such conduct consists of appearing, telephoning or initiating communication or contact at such person's place of employment or business, and the actor was previously clearly informed to cease the conduct."

This last and particularly bold initiative was to provide within the statute, recourse for victims who suffer employment, business or career consequences or reasonable fear in that regard, emanating from the conduct of the stalker, where the stalker has been once clearly informed to cease his conduct. New York State Senator Balboni, who sponsored New York's Stalking Statute, noted that prior to this enactment, there was no recourse for interference with employment and business, even civilly. This salutary provision statutorily recognizes that most stalking is statistically done by former intimate/friends or arises out of or intrudes into the workplace.

With respect to New York's first attempts in criminalizing "Stalking" behavior, in 1992, the New York Legislature only amended the misdemeanor statutes of Menacing. (Penal Law §120.13) (See Appendix for complete wording of the Status ${ }^{\mathrm{i}}$ ) and Harassment (Penal Law \$240.26) ${ }^{\mathrm{ii}}$ 
to the address the problem of one person Stalking another but only in a threatening, frightening or violent way.

The legislative history and legal analysis of anti-stalking laws which began in 1992 with the New York State Legislature recognized that the social deviancy of Stalking warranted stronger legal measures and amended the crimes of Menacing (Penal Law \$120.13) and Harassment (Penal Law \$240.26) to include sections addressing Stalking-like behaviors. It was determined shortly thereafter that even these new laws inadequately addressed the dynamics of anti-social behavior/criminality related to Stalking and the victims in our society.

The high correlation between stalking behavior and the infliction of physical violence or sexual assault was demonstrated by two federal studies. A recent FBI (U.S. Federal Bureau of Investigations) crime report showed that thirty percent of all murdered women are killed by their husbands or boyfriends who stalked them. A November 1997 National Institute of Justice study of stalking found that eighty percent of stalking victims who were stalked by their current or former intimate partner had, at some point in their relationship, been physically assaulted by their partner and thirty-one percent had been sexually assaulted by their partner. In recognition of the real and substantial risk of harm associated with stalking behavior, 49 states enacted anti-stalking laws. In 1992, the N.Y. Legislature took an important step towards recognizing that stalking requires stronger enforcement measures by amending New York's Menacing and Harassment Laws to include stalking behavior within the definition of these crimes. However, with the new act in 1999, New York created the separate crime of stalking. The new law protects victims by providing real and effective sanctions for stalking conduct even at the earliest stages of their anti-social behavior. It also provides increased penalties for repeat offenders; for those offenders who stalk children, for those offenders who possess weapons when stalking, and for those offenders who commit stalking in violation of an order of protection. L.1999, c.635, \$2. ${ }^{2}$

The Legislative History to the new stalking statute is self-explanatory in the necessity for enhanced penalties for stalking behavior. The Legislature found and declared that:

The legislature finds and declares that criminal stalking behavior, including threatening, violent or other criminal conduct has become more prevalent in New York state in recent years. The unfortunate reality is that stalking victims have been intolerably forced to live in fear of their stalkers. Stalkers who repeatedly follow, phone, write, confront, threaten or otherwise unacceptably intrude upon their victims, often inflict immeasurable emotional and physical harm upon them. Current law does not

21999 L Laws of New York, Chapter 635, Section 2. 
adequately recognize the damage to public order and individual safety caused by these offenders. Therefore, our laws must be strengthened to provide clear recognition of the dangerousness of stalking.

In 1999 not satisfied with the previous amendments, the New York Legislature decided to create an additional and separate crime expressly known as "Stalking", and to designate certain degrees of stalking crimes as felonies.

The new statute established Stalking as a separate and distinct crime in New York State. Although some of the antisocial behaviors (criminal acts) associated with this type of offence are addressed in other provisions of the Penal Law regarding Harassment and Menacing, New York was the only state at that time in 1999 that had not established Stalking as a separate and distinct crime punishable with incarceration under the Penal Law.

The Stalking Legislation is designed to serve as a deterrent for those who "stalk" victims. Previous to the enactment of this legislation a defendant, who was known to have called 72 women and threatened to rape their female relatives unless the victim engaged in certain sexual behavior with him was only punishable by misdemeanor prosecution and no more than one year in jail.

The new provisions of Penal Law $\S \$ 120.45$ et seq. recognize the particular nature of this "victim-focused" crime by increasing the level of criminal charge and punishment in cases where the stalker has previously been convicted of one of a list of crimes against the victim or a family member, or those who regularly reside with the victim. The highest level of potential criminal stalking responsibility is established as a Class D Felony, which carries a maximum sentence of up to two and a third to seven $(21 / 3-7)$ years in state prison!

In addition, the New York Stalking Law expands the definition of Stalking to include a situation where an individual engages in "serial stalking" by committing the crime against ten or more persons. The legislative intent was to increase the penalty to a substantial (7 year) state's prison sentence for this type of terrifying anti-social behavior.

The Penal Law in New York divides the crime of Stalking into four degrees, depending upon aggravating circumstances. The basic crime is Stalking in the fourth degree (Penal Law §120.45). (iii See Appendix for full text.)

The four essential elements for a crime of Stalking is that the defendant 1) "intentionally"; 2) for "no legitimate purpose"; and 3) engages in "a course of conduct" directed at a specific person; and 4) must know or "should reasonably know" the person. 
The first basic element of a stalking crime requires a mens rea intent, which is a general mens rea applicable to all intentional crimes. (See full text of Penal Law Section 15.05 in Appendix ${ }^{\text {iv }}$ ) According to the Penal Law a person acts intentionally with respect to a result or to conduct (for example stalking) described by a statue defining a defense when his conscious objective is to cause such result or to engage in such conduct. $^{3}$

The Stalking statute focuses on what the offender does and not what he means by it, or what he intended as the ultimate goal. This is a crucial difference, and in this manner, the Stalking law may hold responsible those "delusional" stalkers who believe that their victims are in love with them or that they can win their victims love by pursuing them" as stated by the NY Court of Appeals case People v. Stuart, 100 N.Y.2d $412)^{4}$.

With respect to the second element of "no legitimate purpose" the Court of Appeals in the Stuart case defined this term to mean "the absence of a reason or justification to engage someone, other than to hound, frighten, intimidate or threaten." Such antisocial conduct is not constitutionally protected and is punishable under the law as a crime. Thus a stalker cannot claim a Constitutional defense of Freedom of Speech or the Freedom of Assembly for his course of conduct against the victim.

Although there is no statutory definition of "course of conduct" (the third basic element) the Courts, through legal precedent have held that an "isolated incident" does not constitute a "course of conduct" as defined by the New York State Court of Appeals case of People v. Valerio, 60 N.Y.2d $669^{5}$. The Court opined that where the violation of Harassment was not proved beyond a reasonable doubt where the only proof was that while picketing on the opposite side of the street from a union headquarters, defendant pointed to a union official as he left the building and stated publicly in a loud voice, "There is the corruption I am talking about, and there is one of the corrupt ones." That constituted proof of neither the course of conduct nor the repeated commission of acts proscribed by the statute (NY Penal Law, \$240.25 subd 5) under which defendant was convicted. Clearly, the NY Court of Appeals found that this type of conduct was not a course of conduct, but rather an isolated incident.

The fourth basic element of stalking is that the criminal must know or "reasonably should know" that his or her conduct will have one of the consequences specified in the statute. Thus the conduct need not actually cause reasonable fear; it is only required that it is "likely" to cause reason-

3 New York Penal Law Section 1505 (1)

4 People v Stuart 100 N.Y.2d 412

5 People v. Valero 60 N.Y.2d 412 
able fear. In this respect New York's Stalking Law is pro-active in penalizing this kind of anti-social behavior.

It must be noted that, the specific Person (victim) has been expanded and is statutorily defined in the Penal Law to include "any other person who regularly resides or has regularly resided in the household of that person"6. Regularly is not defined by this statute and thus under standard statute interpretation it has its ordinary usage and meanings. Thus this provision significantly broadens the protected class of victims to include non-family members of the victim's household provided that they regularly reside with the victim.

The Stalking Statute now protects the victim from three different types of prohibited conduct.

The first alternative conduct under subdivision one is likely to cause reasonable fear of material harm to the physical health, safety or property of such person, a member of such person's immediate family or a third party with whom such person is acquainted.

The second alternative conduct under subdivision two is to cause material harm to the mental or emotional health of such person, where such conduct consists of following, telephoning or initiating communication or contact with such person, a member of such person=s immediate family or a third party with whom such person is acquainted, and the actor was previously clearly informed to cease that conduct.

Under the third alternative consequence of Stalking ( $4^{\text {th }}$ Degree $)$ of Penal Law \$120.45(3) the conduct required: "is likely to cause such a person to reasonably fear..." Here as in subdivision 1 there is no requirement that the conduct in fact caused such reasonable fear, but only that it is "likely" to cause the result. Subdivision 3 specifically spells out the type of conduct required to be performed. Also, most notably, both subdivisions 2 and 3 of this Section require that the defendant be informed to cease such conduct before the conduct is criminally actionable.

The new statute also punishes the recidivist stalker more severely for each subsequent stalking. Stalking in the 3rd Degree, Penal Law ' 120.50 was designed to punish the recidivist stalker more severely for each such actionable behavior. Stalking in the $3^{\text {rd }}$ Degree pursuant to NY Penal Law $\$ 120.50$ provides that the commission of Stalking in the 4th Degree within ten years of the first conviction is Stalking in the $3^{\text {rd }}$ Degree and a class A Misdemeanor punishable by up to one year in jail or three years of misdemeanor probation. Whereas, the lesser crime of Stalking in the $4^{\text {th }}$ degree is a Class B Misdemeanor punishable by up 120 days in jail or by one year of probation.

\footnotetext{
6 New York Penal Law §120.40(4)
} 
Stalking in the $3^{\text {rd }}$ Degree (Penal Law $§ 120.50$ - see Appendix for full text) may be committed three ways. Under subdivisions 1 and 2 there is an initial element of the commission of stalking in the $4^{\text {th }}$ degree and that $4^{\text {th }}$ degree must be against three or more persons "in three or more separate transactions that did form the basis of the previous conviction; or the commission of stalking or the commission of stalking in the $4^{\text {th }}$ degree must be after having been convicted within the preceding ten years of the specified predicate crimes and the victim of the specified predicate crime must have been either the victim of the stalking or immediate family member of that victim."

Under subdivision 3 the crime of stalking in the 3rd degree requires the intent to engage in a course of conduct "likely to cause" the victim to reasonably fear physical injury, a commission of a sex offense, kidnaping, unlawful imprisonment of the person, or such person's immediate family.

Under subdivision 4 stalking in the $3^{\text {rd }}$ degree is complete when the defendant has previously been convicted in the preceding ten years of stalking in the $4^{\text {th }}$ degree.

The more severe crime, a Class E Felony, of Stalking in the $2^{\text {nd }}$ (Penal Law \$120.55 - see Appendix for full text) degree carries a maximum sentence of up to four years in prison or five years of felony probation as a first time offender. The crime of staking in the second degree may be committed in any one of five different ways and it enhances the penalty by way of a felony sentence for basically "serial" stalkers or under subdivision 1 for a stalker who in the course of and in furtherance of the commission of stalking displays or threatens the use of several designated weapons, or under subdivision ii displays "what appears to be a pistol, revolver, shotgun, machine gun, or other firearm." It must be noted that the actor need not actually possess the prescribed firearm, but merely displays what appears to be a "fake" pistol or threatening bulge would be sufficient to satisfy this element.

Finally, the most serious Stalking crime in New York is a Class D Felony of Stalking in the First Degree ${ }^{7}$ carrying a maximum of seven years in states prison or five years of felony probation. This statute is in response to serial stalkers who "cause any physical injury to the victim, ${ }^{\text {"v }}$ or have a previous conviction for Stalking in the $2^{\text {nd }}$ Degree. Physical injury is defined by the NY Penal Law to mean any impairment of a physical condition or creating substantial pain. ${ }^{8}$

7 New York Penal Law $\$ 120.60$ - (See Appendix for full text.)

8 New York Penal $§ 10.00(9)$ 


\section{CONCLUSION}

Enacting anti-stalking legislation is not the end of the story, although it is a good beginning. Although the passing of anti-stalking legislation is important, (it will deter people from stalking, it will save lives,) our attention must be focused on creating social support mechanisms to aid victims of stalking and to enhance legal enforcement and prevention of stalking behavior. It has been suggested that preventive education for children at a young age is important to deter adult stalking behaviors. In the U.S. where money is put into many social programs, such as Domestic Violence; Alternative Drug; and Veteran Courts ${ }^{9}$, and we now need to invest "tax dollars" into social and educational programs to deter stalking behavior. I would suggest a comprehensive approach involving education, law enforcement and appropriate punishment that will effectively lessen the violence and protect people from stalkers.

Nonetheless in New York the Clinic Access and Anti-Stalking Act of 1999 does more than merely protect against stalking as traditionally defined or described, because it expands the proscribed activities to include the following: phoning and/or mailing a target. By legislating protections regarding the safety and lives of victims, their family and household members, and further statutorily protecting the victims' employment, educational and financial lives, New York Penal Law provides the means for victims to take back ownership and control of their lives. Most importantly, the legislation provides the criminal justice system with a way in which to fight the insidious and pernicious conduct that previously was viewed as legally innocuous. What was once viewed before in society as an indiscretion is now culpable and criminal conduct which is prosecutable, and punishable under the Law.

\section{APPENDIX}

\section{Penal Law '120.13 Menacing in the First Degree}

A person is guilty of menacing in the first degree when he or she commits the crime of menacing in the second degree and has been previously convicted of the crime of menacing in the second degree or the crime of menacing a police officer or peace officer within the preceding ten years. Menacing in the first degree is a class $\mathrm{E}$ felony.

\section{ii. Penal Law '240.26 Harassment in the Second Degree}

9 Judge LaBuda has also been designated in New York as a Drug Court and Veteran Court Judge. 
A person is guilty of harassment in the second degree when, with intent to harass, annoy or alarm another person:

1) he or she strikes, shoves, kicks or otherwise subjects such other person to physical contact, or attempts or threatens to do the same; or

2) he or she follows a person in or about a public place or places; or

3 ) he or she engages in a course of conduct or repeatedly commits acts which alarm or seriously annoy such other person and which serve no legitimate purpose.

iv. Penal Law Section 15.05(1). The following definitions are applicable to this chapter: 1. "Intentionally." A person acts intentionally with respect to a result or to conduct described by a statute defining an offense when his conscious objective is to cause such result or to engage in such conduct. 2. "Knowingly." A person acts knowingly with respect to conduct or to a circumstance described by a statute defining an offense when he is aware that his conduct is of such nature or that such circumstance exists. 3. "Recklessly." A person acts recklessly with respect to a result or to a circumstance described by a statute defining an offense when he is aware of and consciously disregards a substantial and unjustifiable risk that such result will occur or that such circumstance exists. The risk must be of such nature and degree that disregard thereof constitutes a gross deviation from the standard of conduct that a reasonable person would observe in the situation. A person who creates such a risk but is unaware thereof solely by reason of voluntary intoxication also acts recklessly with respect thereto. 4. "Criminal negligence." A person acts with criminal negligence with respect to a result or to a circumstance described by a statute defining an offense when he fails to perceive a substantial and unjustifiable risk that such result will occur or that such circumstance exists. The risk must be of such nature and degree that the failure to perceive it constitutes a gross deviation from the standard of care that a reasonable person would observe in the situation.

v. Some states have enacted statutes directed at stalking which have defined the term Acourse of conduct.@A Aleading@ definition is that a Acourse of conduct@ means Aa pattern of conduct composed of a series of acts over a period of time, however short, evidencing a continuity of purpose@ [West=s Florida Statutes Annotated '748.048]. Some states do not use the Ahowever short@ language [Alabama Code '13A-6-92; Rhode Island Statues '11-59-1; Maryland Code, Criminal Law, '3-801 (Maryland also requires that the pattern of conduct be a Apersistent@ pattern of conduct)]; some states instead of requiring a Aseries of acts, @ require two or more acts [Michigan Compiled Laws Annotated, Chapter 750, 
Michigan Penal code '750.411h; North Dakota Century Code, Title 12.1 Criminal code '12.1-17-07.1]. California initially utilized the Aleading@ definition and then amended it to require two or more acts [ Cal. Penal Code present and former section 646.9]. One state couples the Aleading@ definition with examples of the type of conduct that is included in the definition, namely, Aa series of acts of following, detaining, restraining the personal liberty of, or stalking the person or telephoning, contacting, or otherwise communicating with the person.@ [Nebraska Revised Statutes '28-311.02].) Several New York trial courts have utilized the Aleading@ definition [People v Payton, 161 Misc.2d 170, 612 N.Y.S.2d 815 (Criminal Court, Kings County, 1994); People v. Murray, 167 Misc.2d 857, 635 N.Y.S.2d 928 (Criminal Court, N.Y. County, 1995); People v. Monroe, 183 Misc.2d 374, 703 N.Y.S.2d 690 (Criminal Court, N.Y. County, 2000)].

\section{6. '10:00 Definitions of terms of general use in this chapter}

Except where different meanings re expressly specified in subsequent provisions of this chapter, the following terms have the following meanings:

9) APhysical injury@ means impairment of physical condition or substantial pain. 


\section{$\$ 120.50$ Stalking in the third degree}

A person is guilty of stalking in the third degree when he or she:

1. Commits the crime of stalking in the fourth degree in violation of section 120.45 of this article against three or more persons, in three or more separate transactions, for which the actor has not been previously convicted; or

2. Commits the crime of stalking in the fourth degree in violation of section 120.45 of this article against any person, and has previously been convicted, within the preceding ten years of a specified predicate crime, as defined in subdivision five of section 120.40 of this article, and the victim of such specified predicate crime is the victim, or an immediate family member of the victim, of the present offense; or

3. With intent to harass, annoy or alarm a specific person, intentionally engages in a course of conduct directed at such person which is likely to cause such person to reasonably fear physical injury or serious physical injury, the commission of a sex offense against, or the kidnapping, unlawful imprisonment or death of such person or a member of such person's immediate family; or

4. Commits the crime of stalking in the fourth degree and has previously been convicted within the preceding ten years of stalking in the fourth degree.

Stalking in the third degree is a class A misdemeanor. (Added L.1999, c. 635, § 13, eff. Dec. 1, 1999.) 


\section{\$ 120.55 Stalking in the second degree}

A person is guilty of stalking in the second degree when he or she:

1. Commits the crime of stalking in the third degree as defined in subdivision three of section 120.50 of this article and in the course of and in furtherance of the commission of such offense: (i) displays, or possesses and threatens the use of, a firearm, pistol, revolver, rifle, shotgun, machine gun, electronic dart gun, electronic stun gun, cane sword, billy, blackjack, bludgeon, plastic knuckles, metal knuckles, chuka stick, sand bag, sandclub, slingshot, slungshot, shirken, "Kung Fu Star", dagger, dangerous knife, dirk, razor, stiletto, imitation pistol, dangerous instrument, deadly instrument or deadly weapon; or (ii) displays what appears to be a pistol, revolver, rifle, shotgun, machine gun or other firearm; or

2. Commits the crime of stalking in the third degree in violation of subdivision three of section 120.50 of this article against any person, and has previously been convicted, within the preceding five years, of a specified predicate crime as defined in subdivision five of section 120.40 of this article, and the victim of such specified predicate crime is the victim, or an immediate family member of the victim, of the present offense; or

3. Commits the crime of stalking in the fourth degree and has previously been convicted of stalking in the third degree as defined in subdivision four of section $\mathbf{1 2 0 . 5 0}$ of this article against any person; or

4. Being twenty-one years of age or older, repeatedly follows a person under the age of fourteen or engages in a course of conduct or repeatedly commits acts over a period of time intentionally placing or attempting to place such person who is under the age of fourteen in reasonable fear of physical injury, serious physical injury or death; or

5. Commits the crime of stalking in the third degree, as defined in subdivision three of section 120.50 of this article, against ten or more persons, in ten or more separate transactions, for which the actor has not been previously convicted.

Stalking in the second degree is a class $\mathrm{E}$ felony.

(Added L.1999, c. 635, § 13, eff. Dec. 1, 1999; amended L.2000, c. 434, § 4, eff. Oct. 20, 2000; L.2003, c. 598, § 1, eff. Nov. 1, 2003; L.2008, c. 257, § 2, eff. Nov. 1, 2008.) 


\section{\$ 120.60 Stalking in the first degree}

A person is guilty of stalking in the first degree when he or she commits the crime of stalking in the third degree as defined in subdivision three of section 120.50 or stalking in the second degree as defined in section $\mathbf{1 2 0 . 5 5}$ of this article and, in the course and furtherance thereof, he or she:

1. intentionally or recklessly causes physical injury to the victim of such crime; or

2. commits a class A misdemeanor defined in article one hundred thirty of this chapter, or a class $E$ felony defined in section 130.25,

\section{ASSAULT AND RELATED OFFENSES}

Art. 120

\section{\$ 120.60}

130.40 or 130.85 of this chapter, or a class $\mathrm{D}$ felony defined in section 130.30 or 130.45 of this chapter.

Stalking in the first degree is a class D felony.

(Added L.1999, c. 635, § 13, eff. Dec. 1, 1999; amended L.2000, c. 434, § 5, eff. Oct. 20, 2000.)

Physical injury 1

\section{Physical injury}

Evidence that defendant repeatedly punched victim on her face and body. causing bruising that lasted for days,

\section{Notes of Decisions}

swollen and bleeding lips making it difficult to drink, difficulty walking, and substantial pain was sufficient to establish element of physical injury required for conviction of first-degree stalking. People v, Gomez (1 Dept, 2007) 43 A.D.3d 763,842 N.Y.S.2d 21. Assault And Battery $\Leftrightarrow 91.7$ 